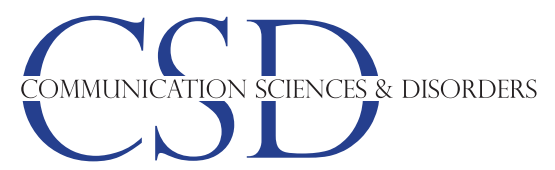

Erratum

| ISSN 2288-0917 (Online) | Commun Sci Disord 2019;24(3):836

\title{
Correction: Research Trends on the Longitudinal Studies of Childhood Stuttering
}

Soo Bok Lee, Hye Yeon Park, Hyun Sub Sim

https://doi.org/10.12963/csd.19605

Commun Sci Disord 2019;24(2):490-506

The Acknowledgments section of the above article incorrectly described. The correct statement should read:

This research was supported by the Ministry of Education of the Republic of Korea and the National Research Foundation of Korea (No. NRF-2018S1A5A2A03036976).

본 논문은 2018년 대한민국 교육부와 한국연구재단의 지원을 받아 수행된 연구임(No. NRF-2018S1A5A2A03036976). 